\title{
ALK Inhibitor PLB 1003
}

National Cancer Institute

\section{Source}

National Cancer Institute. ALK Inhibitor PLB 1003. NCI Thesaurus. Code C148533.

An orally available small molecule inhibitor of the receptor tyrosine kinase anaplastic lymphoma kinase (ALK), with potential antineoplastic activity. Upon oral administration, PLB1003 selectively binds to and inhibits wild-type ALK, ALK fusion proteins and ALK point mutation variants. Inhibition of ALK leads to the disruption of ALK-mediated signaling and inhibits tumor cell growth in ALK-expressing tumor cells. ALK belongs to the insulin receptor superfamily and plays an important role in nervous system development. ALK is not expressed in healthy adult human tissue but ALK dysregulation and gene rearrangements are associated with a series of tumors. ALK mutations are associated with acquired resistance to small molecule tyrosine kinase inhibitors. 